2013

\title{
A Classification Framework for Running Adaptive Management Rapids
}

Melinda Harm Benson

Ryan R. Morrison

Mark C. Stone

Follow this and additional works at: https://digitalrepository.unm.edu/uc_rio_chama

\section{Recommended Citation}

Benson, Melinda Harm; Ryan R. Morrison; and Mark C. Stone. "A Classification Framework for Running Adaptive Management Rapids." (2013). https://digitalrepository.unm.edu/uc_rio_chama/24

This Article is brought to you for free and open access by the The Utton Transboundary Resources Center at UNM Digital Repository. It has been accepted for inclusion in Law of the Rio Chama by an authorized administrator of UNM Digital Repository. For more information, please contact amywinter@unm.edu, Isloane@salud.unm.edu, sarahrk@unm.edu. 


\title{
A Classification Framework for Running Adaptive Management Rapids
}

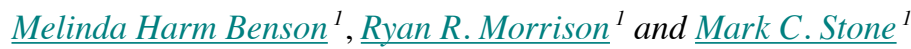

ABSTRACT. While adaptive management (AM) is becoming a preferred natural resource management approach, the conditions necessary to engage in AM are not always present. In order for AM to work, there must be an ability to engage in experimentation and then incorporate what is learned. Just as few rivers are unequivocally either "runnable" or "unrunnable" by a whitewater boater, successful AM depends on a number of factors, including legal frameworks and requirements, resource allocation regimes, and existing infrastructure. We provide a classification framework for assessing the physical and institutional capacity necessary for AM using the international classification for whitewater. We then apply this classification framework to the design of an AM program for New Mexico's Rio Chama. As the case study illustrates, the classification system facilitates learning and provides an engaging way of thinking through problems and involving stakeholders. It can also help keep perceived limitations from becoming fixed reality, and it can be used to develop the conceptual model on which AM is based. The classification system allows practitioners to assess whether AM is possible by providing a way of thinking through the issues involved.

Key Words: adaptive management; conceptual model; Rio Chama; river restoration

\section{INTRODUCTION}

Adaptive management (AM) is growing in popularity among natural resource managers because of its capacity to address management challenges that involve high degrees of variability and uncertainty. Particularly in the face of global climate change, managers are looking for management tools that provide increased flexibility and opportunities for learning. The conditions necessary for AM to be successful, however, are not always present (Porzecanski et al. 2012). In order for AM to be successful, there must be both the institutional and physical capacity to engage in AM. Relevant questions include whether management actions be adjusted in response to what has been learned and whether an AM process can be established within the appropriate legal framework (Williams et al. 2009). There are rarely "yes" or "no" answers to these questions. Instead, there is often a continuum of capacity to manipulate both the ecological and social aspects of any given system and make the necessary adjustments to accommodate AM.

In their seminal paper on adaptive governance, Olsson et al. (2006) invoke the metaphor of "shooting the rapids" to describe the challenges of negotiating the ongoing turbulence observed in social-ecological systems that are facing transformational change. Extending this metaphor, we use the international classification framework for whitewater to create an assessment process for evaluating the level of challenge associated with creating the necessary physical and institutional conditions for AM. Just as a whitewater boater must negotiate rapids that involve varying degrees of difficulty, an AM practitioner often faces a number of challenges at various degrees of complexity when implementing an AM program. And, like a whitewater boater, an AM practitioner is advised to do the necessary research and situation scouting to determine whether these challenges can be negotiated successfully.

In order to demonstrate the possible utility of our classification framework, we examine the potential for developing AM strategies for water operations in New Mexico's Rio Chama watershed as part of the Rio Chama Optimization Project (Optimization Project). As with many dam controlled river systems in the American West, successful AM of the Rio Chama requires not only the physical ability to manipulate the system via dam storage and releases, but also an appropriate amount of institutional capacity, including the necessary administrative flexibility and authority needed to manipulate flows. We employ the National Research Council's definition of AM, which is included in the U.S. Department of Interior's technical guide for AM implementation, explains:

Adaptive management [is a decision process that] promotes flexible decision making that can be adjusted in the face of uncertainties as outcomes from management actions and other events become better understood. Careful monitoring of these outcomes both advances scientific understanding and helps adjust policies or operations as part of an iterative learning process. Adaptive management also recognizes the importance of natural variability in contributing to ecological resilience and productivity. It is not a 'trial and error' process, but rather emphasizes learning while doing. Adaptive management does not represent an end in itself, but rather a means to more effective decisions and enhanced benefits. Its true measure is in how well it helps meet environmental, social, and economic 
goals, increases scientific knowledge, and reduces tensions among stakeholders (Williams et al. 2009, p. 4).

We developed the framework as team members of the Optimization Project, and we offer it as a theory-building exercise and as a possible way of determining when AM can be successful. We also suggest that it can be used to develop more accurate (and therefore more useful) conceptual models of the social-ecological system (SES) dynamics in which AM will take place. The conceptual models commonly used to understand SES dynamics of water operations are often embedded with assumptions about both physical and institutional capacity. As will be explained, these assumptions are not always accurate, and when recognized, can be reexamined with opportunities for AM in mind. We argue that by looking at the issues concerning legal and institutional capacity as a continuum, many issues, challenges, or concerns that may initially look insurmountable may in fact be amenable or even beneficial to AM.

When considering if AM is appropriate, the function of conceptual and numerical models used is important and can help managers determine whether AM is the right course of action (Peterson et al. 2003). Appropriate models need to both represent system uncertainty and be flexible enough to allow experimentation of hypotheses, and both of these components are often missing. Instead of being integrated experimental tools, models are typically used to predict ecosystem responses to management decisions so that a single "best" management approach can be selected (Prato 2003). Models may then be incrementally revised based on monitoring results to support the chosen approach. Inevitably, institutional assumptions regarding capacity become embedded in models used in this way. Numerous sources of uncertainty are neglected with this approach, including varying ecosystem responses to management decisions, monitoring-data uncertainty, and complex relationships between other components in the system. Prato (2003) compares the former use of modeling (passive management) to the more experimental active management approach. Modeling should support experimentation of management hypotheses so that valid data about management effects on socioeconomic and ecological conditions can be assessed.

\section{PROPOSED CLASSIFICATION SYSTEM}

Just as a skilled whitewater boater would first study a river reach, managers and programs engaging in AM can benefit from an upfront, explicit evaluation of potential obstacles or constraints in order to determine (1) how difficult they will be, (2) whether any particular approach might provide the best outcome, and (3) whether to attempt it at all. We adapt the international whitewater classification system to create a framework for assessing physical and institutional capacity to engage in AM (Table 1). The classification ranges from easy
(Class I) to extremely dangerous, even for seasoned experts (Class VI).

Class I waters are straightforward; no impediments are present. A seasoned whitewater boater would simply go with the current. Similarly, Class I AM conditions present no obstacles.

Class II water requires the attention of the boater, but the water can be successfully negotiated with minimal maneuvering. In the AM context, a Class II situation might require some education of the relevant stakeholders to ensure they understand and support the action or might require a cursory environmental review, for example an environmental assessment under the National Environmental Policy Act (NEPA) (Benson and Garmestani 2011).

Class III water requires significant attention and careful maneuvering from even an experienced boater, but the obstacles should not impede downstream progress. A Class III AM situation does not require new laws or system engineering, but it may require administrative rule-making, use of administrative flexibility that is not often engaged, or physical manipulations of the ecological system that go beyond generally accepted practice. For example, the reintroduction of a nonessential/experimental population under the Endangered Species Act requires the federal wildlife agency to engage in administrative rule-making and associated public notice and comment. While these challenges are surmountable, careful attention and precise maneuvering is required.

Class IV rapids are tricky. A Class IV AM situation almost always requires some type of legal or physical change to the SES to create the necessary capacity to engage in AM. For example, congressional approval may be required to authorize a new watershed management program and provide the necessary funding, as was the case for the Platte River Restoration Program (Smith 2011). Class IV requires considerable effort and strategy, and project team members and stakeholders will likely need to "scout" the necessary capacity issues via both formal and informal processes. When on the river, "scouting" usually means getting your boat out of the main channel, tying it up to the river bank, and walking upstream and downstream along the bank to assess the overall situation before actually getting back in the boat and running the rapid. In AM terms, scouting requires temporarily stopping the process in order to conduct a careful examination of the physical and legal hurdles that may pose dangerous obstacles to moving forward.

Class V water is both difficult and dangerous. Class V AM rapids require significant physical or institutional change. Examples include dam reconfiguration or change in land management designation. 
Table 1. Translation of international whitewater classification to classification of institutional and physical capacity to engage in adaptive management (AM).

\begin{tabular}{|c|c|c|c|c|c|}
\hline $\begin{array}{c}\text { Classification system } \\
\text { I }\end{array}$ & II & III & IV & $\mathrm{V}$ & VI \\
\hline \multicolumn{6}{|c|}{ International whitewater classification } \\
\hline $\begin{array}{l}\text { Moving water with a } \\
\text { few riffles and small } \\
\text { waves. Few or no } \\
\text { obstructions }\end{array}$ & $\begin{array}{l}\text { Easy rapids with } \\
\text { smaller waves, clear } \\
\text { channels that are } \\
\text { obvious without } \\
\text { scouting. Some } \\
\text { maneuvering might be } \\
\text { required }\end{array}$ & $\begin{array}{l}\text { Rapids with high, } \\
\text { irregular waves. } \\
\text { Narrow passages that } \\
\text { often require precise } \\
\text { maneuvering }\end{array}$ & $\begin{array}{l}\text { Long, difficult rapids } \\
\text { with constricted } \\
\text { passages that often } \\
\text { require complex } \\
\text { maneuvering in } \\
\text { turbulent water. The } \\
\text { course may be hard to } \\
\text { determine and scouting } \\
\text { is often necessary }\end{array}$ & $\begin{array}{l}\text { Extremely difficult, } \\
\text { long, and very violent } \\
\text { rapids with highly } \\
\text { congested routes, } \\
\text { which should be } \\
\text { scouted from shore. } \\
\text { Rescue conditions are } \\
\text { difficult, and there is a } \\
\text { significant hazard to } \\
\text { life in the event of a } \\
\text { mishap. The upper limit } \\
\text { of what is possible in a } \\
\text { commercial raft }\end{array}$ & $\begin{array}{l}\text { The difficulties of Class } \\
\text { V carried to the } \\
\text { extreme. Nearly } \\
\text { impossible and very } \\
\text { dangerous. For teams of } \\
\text { experts only. Involves } \\
\text { risk of life. Class VI } \\
\text { rapids are not } \\
\text { commercially passable }\end{array}$ \\
\hline \multicolumn{6}{|c|}{ Classification of physical and institutional capacity to engage in AM } \\
\hline $\begin{array}{l}\text { No problem. Capacity } \\
\text { exists to engage in AM }\end{array}$ & $\begin{array}{l}\text { Conditions generally } \\
\text { support AM, but "some } \\
\text { maneuvering" such as } \\
\text { public education or } \\
\text { management } \\
\text { authorizations that are } \\
\text { easily obtained may be } \\
\text { necessary. Routine } \\
\text { adjustments to } \\
\text { infrastructure }\end{array}$ & $\begin{array}{l}\text { AM possible without } \\
\text { structural changes to } \\
\text { the social-ecological } \\
\text { system (SES), but } \\
\text { careful groundwork } \\
\text { must be done (e.g., } \\
\text { promulgating new } \\
\text { regulations or leasing } \\
\text { water rights) }\end{array}$ & $\begin{array}{l}\text { Capacity must be } \\
\text { created to support AM. } \\
\text { Making these changes } \\
\text { will take considerable } \\
\text { effort and maneuvering } \\
\text { (e.g., congressional } \\
\text { appropriations or need } \\
\text { to assess physical } \\
\text { integrity of dam } \\
\text { infrastructure) }\end{array}$ & $\begin{array}{l}\text { Significant changes to } \\
\text { social-ecological } \\
\text { system necessary to } \\
\text { create capacity for AM } \\
\text { (e.g., substantive } \\
\text { legislative change or } \\
\text { reconfiguration of dam) }\end{array}$ & $\begin{array}{l}\text { Extremely difficult to } \\
\text { create capacity. } \\
\text { Fundamental changes to } \\
\text { social-ecological system } \\
\text { needed (e.g., } \\
\text { international treaty } \\
\text { renegotiation, } \\
\text { constitutional } \\
\text { amendments or dam } \\
\text { removal) }\end{array}$ \\
\hline
\end{tabular}

The last classification, Class VI, is theoretically runnable but extremely difficult and dangerous, to the extent that most boaters will not consider attempting the rapids. In the institutional context, a Class VI AM situation might require renegotiation of an international treaty, a constitutional amendment, or dam removal.

\section{CASE STUDY: NEW MEXICO'S RIO CHAMA}

The Rio Chama is the major upper basin tributary to the Rio Grande and is located in northern New Mexico, U.S.A. The focus of this case study is the $50-\mathrm{km}$ reach between the El Vado Dam and Abiquiu Reservoir (Fig. 1). This section of the Rio Chama was federally designated as a Wild and Scenic River in 1988 in recognition of its environmental, recreational, and aesthetic qualities, and is popular among recreational boaters. It provides a three-day boating adventure with only a few Class II and Class III rapids. Running an AM program on the Rio Chama, however, is considerably more challenging. Like many rivers in the American West, reservoirs and hydroelectric dams confine the river. Construction of El Vado (1935), Heron (1974), and Abiquiu (1954) dams has altered the Rio Chama's hydrologic regime. Present operation of the dams causes occasional dewatering of the river (flows $<1 \mathrm{~m}^{3}$ / s) and can release flows as high as $175 \mathrm{~m}^{3} / \mathrm{s}$ (6180 cfs). Releases are determined primarily by water demands in the downstream Rio Grande valley, although a multi-agency agreement provides summertime weekend releases to allow
Fig. 1. Rio Chama watershed and location map including El Vado and Abiquiu reservoirs. Water is transferred into the basin via the San Juan-Chama Project through Willow Creek.

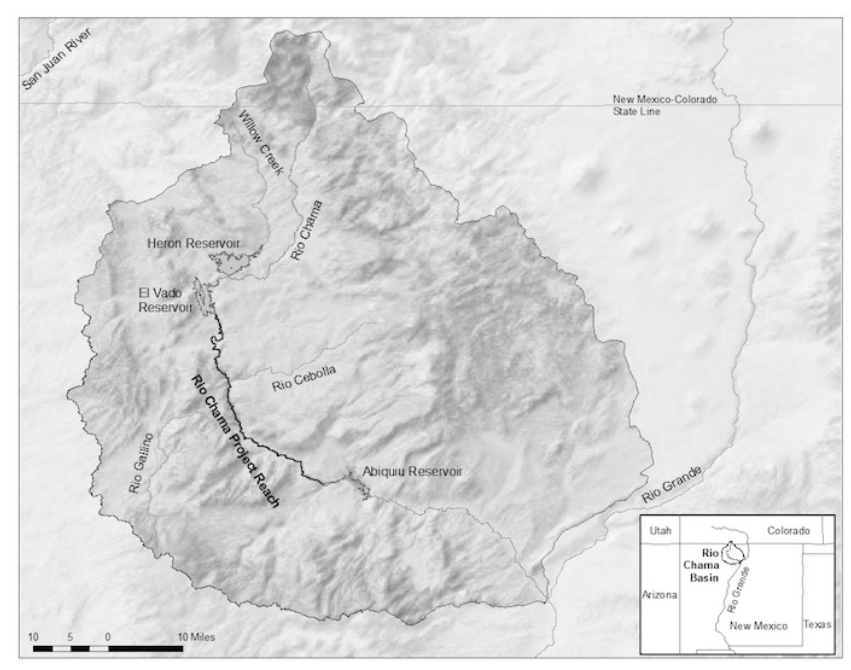

whitewater boating, primarily using the City of Albuquerque's water supply, during times in which irrigation water is not being released from the reservoirs. These management 
conditions have led to considerable manipulation of streamflows from background conditions (Fig. 2). The most severe modifications of streamflows include reductions in peak flows in the spring and augmentation of summer and early fall flows. During times that irrigation water is not being released from El Vado Dam for irrigation, summer flows are characterized by sharp changes in discharge each weekend to support whitewater boating (flows increase quickly on Friday mornings and decrease on Sunday evenings). There are also hydropower facilities located at both El Vado and Abiquiu dams. Both power stations are operated by Los Alamos County and have a combined generation capacity of approximately 26 MW (enough to power approximately 10,000 homes).

The Rio Chama is widely known for its role in the U.S. Department of Interior's Bureau of Reclamation's San JuanChama Diversion Project (SJC Project), a trans-basin diversion of 125 million $\mathrm{m}^{3}$ (96,000 acre-ft) of water annually from the Colorado River Basin to the Rio Grande watershed as authorized under the Colorado River Compact. The SJC Project water provides an opportunity for experimentation in SES dynamics because the additional water increases annual river volume by approximately $40 \%$ of average historical conditions. This water is stored in Heron and El Vado reservoirs and then delivered to downstream users for municipal and agricultural purposes (Flanagan and Hass 2008). Because water released from El Vado can be stored downstream at Abiquiu Reservoir (a flood control project operated by the U.S. Army Corps of Engineers), there is an opportunity to engage in experimental flow operations. Experimental flows can be released from El Vado, then held in Abiquiu Reservoir and released later as needed for water deliveries downstream.

Interest in the potential efficacy of environmental flows came as a result of an unintentional "scouting" of the Rio Chama's physical capacity. In 2009, rapid snowmelt followed by the threat of a rain-on-snow event required the emergency controlled release of $159 \mathrm{~m}^{3} / \mathrm{s}$ (5600 cfs) from El Vado Reservoir. Although this discharge was equivalent to the historic 2-year recurrence interval peak flow prior to the construction of El Vado Dam, it was the largest discharge released from the reservoir since 1985. The resulting geomorphic changes within the channel surprised many stakeholders and demonstrated that similar flows could be released safely (i.e., without damaging basic infrastructure) from El Vado Reservoir in order to improve downstream geomorphic and ecological conditions.

The 2009 high flow event sparked interest in the possibility of reintroducing pulse flows to the river system in order to enhance ecological function. In 2010, a group of interested stakeholders sought and received funding from the State of New Mexico for the Optimization Project. The effort involves researchers and stakeholders from more than a dozen entities
(Table 2). The long-term goal of this effort is to develop an operational plan that will enhance the channel dynamics and ecological functions of the Rio Chama between El Vado and Abiquiu reservoirs. The project aims to develop an adaptive environmental flow prescription that (1) preserves or enhances ecosystem conditions in the Wild and Scenic section of the Rio Chama, (2) meets the needs of river-oriented recreation (trout fishing and whitewater boating), and (3) improves the reliability and output of hydropower systems at the dams, while also (4) achieving the current management objectives of maintaining water storage and delivery for irrigators, tribes, and municipalities. Current project funding is focused on an intensive baseline data collection effort (geomorphic, riparian, and aquatic habitat), stakeholder outreach activities (both to educate and build support for the project), and system dynamics modeling. We are a part of the project team engaged in this effort, and we created the classification system as a result of finding ways to communicate with each other across our disciplinary expertise. As enthusiastic boaters ourselves, many of our conversations took place while on the river or around the campfire as we discussed the various challenges of implementing an adaptive flow regime for this section of the Chama River.

Fig. 2. Examples of Rio Chama hydrographs for unaltered (reconstructed) and altered conditions. The unaltered and altered hydrology are based on USGS Gages 08284100 and 08285500 , respectively. Insets show hydrographs through the water delivery portion of the 2001 water year.

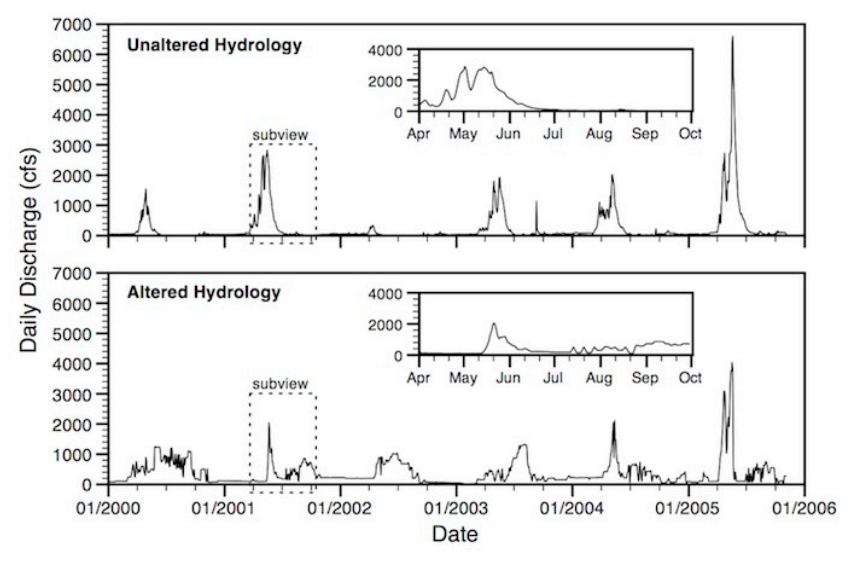

\section{APPLYING THE CLASSIFICATION FRAMEWORK}

Working within existing institutional commitments and constraints, the Optimization Project proposes to enhance both the social and ecological benefits of the river. There are a number of the current institutional capacity issues that can be examined using the classification system (Table 3 ). To begin, management of the Rio Chama is subject to New Mexico's 
Table 2. Key constituencies and managers involved in the Rio Chama case study.

\begin{tabular}{|c|c|}
\hline Stakeholders & Role in the Optimization Project \\
\hline U.S. Bureau of Reclamation & Federal agency that operates Heron, El Vado, and Elephant Butte dams primarily for water storage and delivery \\
\hline U.S. Army Corps of Engineers & Federal agency that operates Abiquiu Dam primarily for flood control \\
\hline $\begin{array}{l}\text { New Mexico Office of the State Engineer } \\
\text { and Interstate Stream Commission }\end{array}$ & $\begin{array}{l}\text { The state agency responsible for administering the state's water resources; the Interstate Stream Commission is } \\
\text { responsible for interstate compact compliance }\end{array}$ \\
\hline Los Alamos County & $\begin{array}{l}\text { Local government that owns and operates two hydroelectric plants at Abiquiu and El Vado dams and would } \\
\text { like ability to increase production to meet peak demand }\end{array}$ \\
\hline Water rights holders & $\begin{array}{l}\text { Entities and individuals (including the Chama Valley irrigators, Middle Rio Grande Conservancy District, } \\
\text { Albuquerque-Bernalillo Water Utility Authority, and City of Santa Fe) who use San Juan Chama Project water } \\
\text { for irrigation and municipal purposes or whose water withdrawals are within the project area }\end{array}$ \\
\hline Adjacent landowners & $\begin{array}{l}\text { Landowners who own property (1) along project reach (including federal land managers U.S. Forest Service } \\
\text { and Bureau of Land Management, Christ Church of the Desert Monastery, and El Vado Ranch) or (2) adjacent } \\
\text { to Abiquiu Reservoir }\end{array}$ \\
\hline $\begin{array}{l}\text { Trout Unlimited and commercial fishing } \\
\text { guides }\end{array}$ & Anglers who fish the Rio Chama and seek enhancement of the brown trout fishery \\
\hline Rafting community & $\begin{array}{l}\text { Private and commercial boaters who raft the Wild and Scenic stretch of the Rio Chama and seek adequate and } \\
\text { predictable dam releases from El Vado for recreational purposes }\end{array}$ \\
\hline Rio Grande Restoration & $\begin{array}{l}\text { Environmental nongovernmental organization currently responsible for the development and implementation of } \\
\text { the Optimization Project }\end{array}$ \\
\hline
\end{tabular}

commitments under the Rio Grande Compact between Colorado, New Mexico, and Texas (Flanagan and Haas 2008). Article VII of the Compact limits the times during which water can be stored at El Vado; it states that when the volume of usable water for the downstream Rio Grande Project stored at Elephant Butte Reservoir is below $4.9 \times 10^{8} \mathrm{~m}^{3}$ (400,000 acrefeet), New Mexico cannot store additional irrigation water in El Vado. Changes to the Compact are a Class VI constraint: these agreements are rarely revisited. "Deviations" from the Compact, however, can be achieved if the Rio Grande Compact Commission grants an exception on a case-by-case basis. For example, exceptions have been authorized to provide pulse flows from Cochiti Reservoir on the Rio Grande (downstream of the case study area) to benefit the Rio Grande Silvery Minnow (Hybognathus amarus), a listed species under the Endangered Species Act (Utton Transboundary Resource Center 2012). Any deviation would likely trigger an environmental review under NEPA and consultation with certain Native American tribes. At this point, it is not clear whether a deviation would be required to provide the water storage needed to support environmental flows. If a deviation could support environmental flows, negotiating this change would be a Class IV constraint-difficult, but not impossible.

Second, like many rivers and streams in the American West, the water within New Mexico's rivers is allocated for downstream use in accordance with the prior appropriation doctrine. Article XVI of the New Mexico Constitution establishes the basic principles underlying New Mexico water law, including the prior appropriation doctrine, which allocates water based on a seniority system (Utton Transboundary Water Resource 2012). In the case of the Optimization Project, there is no intention of altering existing water allocation regimes. Any environmental flow operations would be designed to avoid injury to water rights ("Injury" is a legal term meaning the water rights holder receives less water than he or she is entitled to under the prior appropriation doctrine). Avoiding injury would not require any changes to legal authorizations; however, the precise maneuvering required, when combined with the collaborative processes necessary to gain the support of water rights holders, make this a Class III challenge.

In order to avoid injury, any experimental flows would need to be stored in Abiquiu Reservoir. Storage authority involves a number of legal issues, including the easements that authorize the flooding of land owned by surrounding landowners. Storage of water would have to be in accordance with existing easement authorizations held by the Albuquerque-Bernalillo Water Utility Authority (ABWUA) for storage of SJC Project water. While storage issues will probably not pose any difficulty, communication with easement holders and permission from ABWUA would be required. At least some maneuvering would be necessary, resulting in a Class II designation.

Next, SJC Project contractors do not take possession of their annual allocation of water until it is released from Heron Reservoir. While the legislative authority is silent on the issue, the general institutional consensus is that contractors must take possession of their annual allocation by December 31 of a given year or they lose the allocation. Contractors may request a waiver of the December 31 release date until September 30 of the following year, but Reclamation generally will not grant such a waiver unless it is beneficial to the federal government (Flanagan and Haas 2008). This institutional constraint is a "must scout" Class IV because the Optimization Project may require a waiver. While there is an open legal question 
Table 3. Institutional capacity issues in the Rio Chama case study.

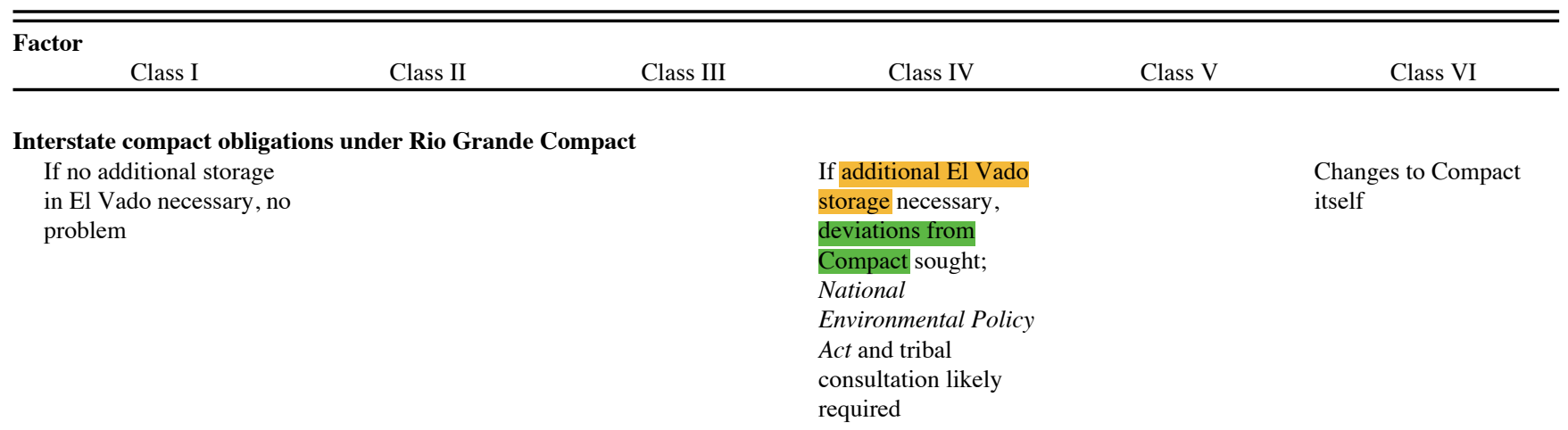

Water allocation regimes (prior appropriation) and associated water delivery requirements under state water law

$$
\begin{aligned}
& \text { Changes to timing of } \\
& \text { water deliveries for } \\
& \text { flow optimization in a } \\
& \text { way that does not } \\
& \text { injure water rights or } \\
& \text { harm public interest }
\end{aligned}
$$

Changes to Compact

Changes to state statutes implementing allocation system and management of water

Constitutional change to water allocation away from prior appropriation doctrine

Storage authority at Abiquiu

Legally no obstacles, but storage will have to be within existing easement authorizations, and landowner education and outreach is important

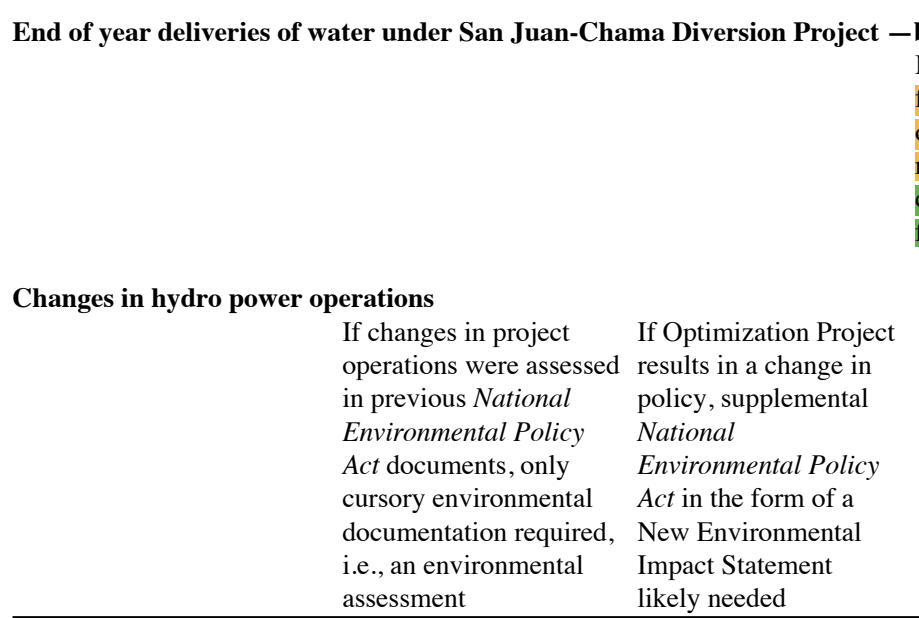

-beyond Jan $1^{\text {st }}$

Must scout! Waiver

from project delivery

obligations may be

required, including

demonstration of

federal interest regarding whether the possession requirement is mandatory, it is likely that a demonstrated federal interest will need to be verified (for example, enhancement of the Wild and Scenic values of the reach).

Finally, among the Optimization Project goals is an attempt to better suit Los Alamos County's need for hydropower. Currently, the county has no legal control over reservoir releases that generate this power. This is unfortunate because the county is part of a regional cooperative that requires it to reserve $1 \mathrm{MW}$ of production capacity on-call to be delivered within 10 minutes. This production capacity is referred to as "spin-reserve," and the county currently leases generation capacity at the Four Corners Power Plant at a cost of US\$400,000 per year to meet this requirement. If the county could instead request modest flow releases (approximately 1.5 $\mathrm{m}^{3} / \mathrm{s}$ or $12 \%$ of summer mean flows at both El Vado and Abiquiu dams for one hour) to satisfy its "spin-reserve" obligation, it could move to this more affordable and renewable form of energy. The county could also achieve a 
Table 4. Physical capacity issues in the Rio Chama case study.

\begin{tabular}{|c|c|c|c|c|}
\hline $\begin{array}{l}\text { Physical factors } \\
\text { Class I }\end{array}$ & Class II & Class III & Class IV & Class V \\
\hline
\end{tabular}

EI Vado Dam outlet works/hydropower facility capacities Discharge capacities are greater than flow rates needed by the Optimization Project

El Vado Dam spillway capacity

The spillway is not needed

to meet project goals

Channel capacity near private property in floodplain

Property located along the channel begins to flood at approximately $170 \mathrm{~m}^{3} / \mathrm{s}$. Construction of berms or compensation/ relocation of threatened structures are possible
Evaporative losses at reservoirs
The outlet works and/or hydropower facility would have to be modified or rebuilt to accommodate greater flows.

The spillway is currently unsafe for use. No water is allowed over the spillway, even if its use is needed to meet goals of the

Optimization Project

Increased evaporative losses
at Abiquiu Reservoir can be
managed through
negotiations with
stakeholders, strategically
timed releases of water to
minimize evaporative losses,
and monetary compensations
to water users

significant increase in revenue through small adjustments in the timing of power generation. The high water releases on the weekends to support the whitewater boating community currently provide maximum production at a time when the value of power is very low, and, if there are no irrigation releases from El Vado Reservoir, power generation drops rapidly when the rates rise on Monday. Changes to current operation of these dams to better accommodate the county's power needs may require additional environmental review under NEPA. These reviews would make this either a Class II or Class III constraint depending on the level of authorization and environmental review required.

Whereas institutional capacity issues on the Rio Chama result from governance structures, physical capacity issues are caused primarily by natural resource limitations and operational constraints (Table 4). The first constraint is perhaps the most obvious: a limited amount of water is in the system at any given time, and depending on availability, may or may not be available for experimental environmental flows.
Upper limits for peak releases from El Vado Reservoir also impose physical capacity challenges on the Rio Chama. Besides small local and tributary inflows, water is supplied to the project reach using controlled releases from the reservoir. Water is passed downstream using the dam's hydropower facility, outlet works, and emergency spillway, typically in that order. The outlet works consist of two concrete tunnels through the dam embankment with gates to regulate flows leaving the reservoir. The hydropower plant discharges water through a single steel pipe and a regulating gate (Fig. 3). A spillway was also constructed to pass emergency flows that exceed the combined capacities of the outlet works and hydropower facility.

The outlet works and hydropower facility have maximum discharge capacities of approximately $190 \mathrm{~m}^{3} / \mathrm{s}$ (6700 cfs) and $34 \mathrm{~m}^{3} / \mathrm{s}$ (1200 cfs), respectively. The classification of this physical constraint depends on the maximum discharges needed to meet the ecological goals of the Optimization Project. If flows greater than the combined capacities of the 
outlet works and hydropower facility are not required to meet project goals, this physical capacity issue is a Class I constraint and will not be a limitation. However, if the combined discharge capacities are unable to meet the Optimization Project's desired flow rates, this physical constraint is a Class $\mathrm{V}$ constraint. Structural modifications or complete rebuilds of the outlet works and hydropower facility would be necessary to accommodate greater discharges.

Fig. 3. A view of El Vado Dam and spillway looking upstream.

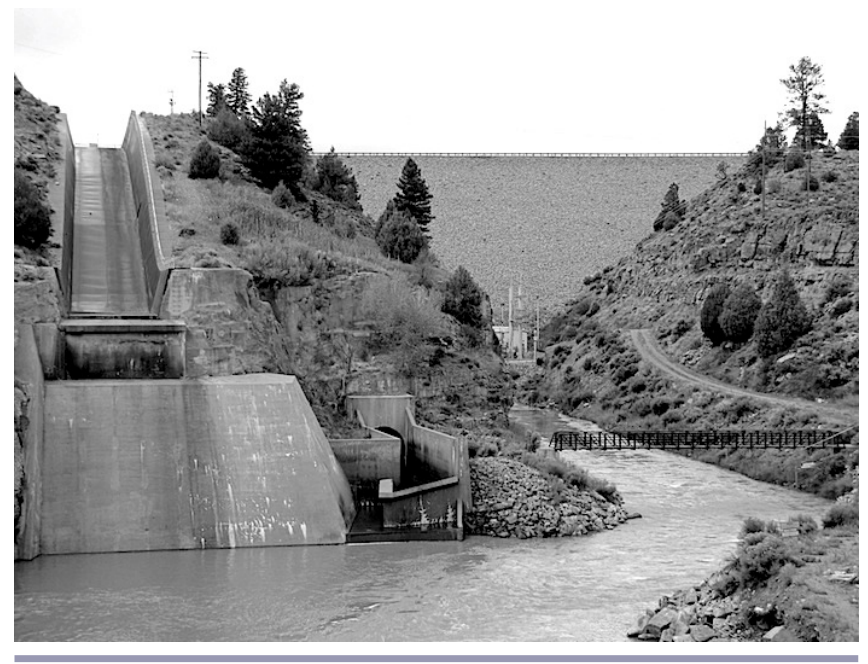

Although the spillway at El Vado Dam was designed to safely bypass flows when the outlet works and hydropower facilities are operating at maximum capacity, deterioration of the spillway structure has made it inoperable. The use of the spillway will threaten the overall safety of the dam and is therefore unconditionally prohibited for passing water to meet any Optimization Project goals. However, this constraint becomes problematic only if the spillway is needed to meet project discharge requirements. Similar to the maximum discharge limitations of the outlet works and hydropower facility, this physical capacity issue is a Class I constraint if the Optimization Project does not require the operation of the spillway to deliver high flows. But, if the spillway is essential for releasing high flows, the prohibited use of the spillway is classified as a Class VI constraint. The ranking of this physical constraint hinges on the specific requirements of the Optimization Project for its flow regime experiments.

Infrastructure encroachments within the floodplain create another physical capacity issue. Flows greater than approximately $170 \mathrm{~m}^{3} / \mathrm{s}(6000 \mathrm{cfs})$ would risk impact to private property in one section of the river. If flow rates greater than $170 \mathrm{~m}^{3} / \mathrm{s}$ are needed to meet project goals, the flooding issue can be mitigated in numerous ways. Small berms constructed around the threatened structures would protect the private property from bank erosion resulting from high flow events. Other solutions include compensating property owners for flood damage, specifically farmland loss during flooding, or relocating threatened structures to an area unaffected by floodwaters. Because mitigation of this physical constraint requires construction of new structures or major modification of existing structures, it is classified as a Class IV constraint.

Differences in evaporative loss rates between Heron, El Vado, and Abiquiu reservoirs also influence how the system is operated. Managers try to maximize water storage in El Vado and Heron reservoirs since evaporative losses are lower at these higher elevation reservoirs. This strategy conflicts with some of the Optimization Project's ecological goals, which require water to be passed downstream and stored in Abiquiu Reservoir, at a lower elevation. Increased losses due to evaporation in Abiquiu Reservoir would need to be subtracted from one or more water users' allocated supply for the year. This physical capacity issue could be solved through a variety of means, including negotiations with stakeholders, strategically timed releases of water to minimize evaporative losses, and monetary compensations to water users for losses due to prolonged storage in Abiquiu Reservoir. While somewhat difficult, there is a range of options available for resolving this issue, making it a Class III constraint.

\section{DISCUSSION}

Like many contexts in which AM strategies are employed, the Rio Chama Optimization Project is comprised of a complex set of legal requirements, physical constraints, and both social and ecological enhancement opportunities. As a project team, we are using the classification system as a tool for the design and implementation of an AM program in several ways.

First, we hope to use it to facilitate project development and stakeholder involvement. Especially for individuals already familiar with whitewater boating, the classification system provides an understandable and accessible analogy that cuts across disciplinary training and professional background, which enables participants to better understand how various individuals perceive the requirements of the project. By presenting our initial sense of the "class" of each rapid, we will be providing a starting point for discussions regarding both the level of difficulty and our proposed approach for addressing each capacity question. We anticipate that we will need to adjust our capacity classifications based on stakeholder feedback, perhaps multiple times, before we engage in experimental flows. For example, one of the possible scenarios for experimental flows would involve changing the delivery dates for end-of-year releases of SJC Project water. Currently, releases of SJC Project water begin in mid-November in order to fully deliver the allocated volume by the end of the calendar year. These end-of-year flows trigger brown trout spawning on gravel bars that are inundated by the high water. After the 
SJC Project water is delivered, flows are dramatically reduced and the spawning redds become exposed, desiccated, and destroyed. We hypothesize that if the delivery of the SJC Project water begins earlier in the fall, the dramatic fluctuation could be decreased and brown trout spawning redds could be less impacted. By classifying the issue as a Class IV constraint, we can begin a discussion with Reclamation, water contract holders, anglers, and others about the potential for this particular experiment, the legality of such a waiver under the Colorado River Compact, and the need for demonstration of a federal interest and how to offset possible evaporative losses as previously discussed.

These issues highlight the second way in which the classification system is a useful tool: it helps keep perceived limitations from becoming reality. How practitioners and stakeholders perceive a rapid's level of difficulty is often more important than the legal, institutional, or physical realities at issue. This is particularly true in the instance of water allocation systems in the West-past is often prologue. By their nature, experimental environmental flows present a new way of operating a water delivery system. "We've always done it that way" explanations for current approaches may or may not be grounded in some inviolable legal or institutional regime. For example, the physical capacity currently exists for Los Alamos County to remotely adjust flows as needed for short-term spin-reserve power production using a supervisory control and data acquisition system, which removes the need for manual changes in operations at El Vado Dam. When flows are passed through only the hydropower facility, the county can save workforce requirements and money by operating reservoir releases from afar, while also fine-tuning hydropower production to accommodate spin-reserve operations and downstream water delivery needs. Though the technology is there, it is not used because, traditionally, Reclamation manually manipulates flows on location at El Vado Dam. The extent to which institutional constraints (including water and storage rights) will be a limiting factor is an important issue. The classification system provides a vehicle for identifying assumptions and creating consensus regarding existing realities.

Third, the classification system provides a tool for incorporating capacity issues into management and decisionmaking models of social-ecological systems. Although computer models are not necessary for every AM project, they can help explore sources of uncertainty in complex systems. Numerous sources of uncertainty exist in any project, including varying ecosystem responses to management decisions, monitoring-data uncertainty, complex relationship between components in the system, and institutional and physical capacities in the system. Though experimentation of management strategies is useful for hedging against system uncertainty, models should explicitly address uncertainty when possible. Probabilistic inputs and stochastic modeling can help managers maximize ecological benefits across a range of possible management choices (Walters and Hilborn 1978). For example, Bayesian belief networks provide a conceptual view of system uncertainty and can calculate outcome probabilities for multiple management options (Nyberg et al. 2006). As AM is applied to larger and more complex systems, the inclusion of uncertainty during model development will become more important.

Timing will also be an important factor for both project design and implementation. As the Greek philosopher Heraclitus famously stated: "No man ever steps in the same river twice." Rivers change, depending on flow conditions, channel alterations, and other factors. These factors impact the level of difficulty an issue presents at any given time. As a result, any classification of a given rapid is necessarily subject to conditions at the time the rapid is run. Almost all of the physical capacity issues can be addressed if there is an increased level of "flow" in terms of financial support. For example, if the Optimization Project is able to acquire the necessary funding to lease water rights and/or compensate for evaporation losses associated with storage downstream, it might be able to bypass the Class III issue associated with avoiding injury to water rights holders. Similarly, many of the Rio Chama's institutional rapids will be much easier if there is a high level of support from Reclamation and other stakeholders, and this will inevitably take an investment of time and resources.

In addition to timing, there is a need for a number of different types of expertise. The Optimization Project currently involves engineers, geomorphologists, hydrologists, ecologists, and legal scholars, each of whom bring their own disciplinary perspective to the challenges ahead. Many of the team members have extensive experience related to the Rio Chama, but few have experience with AM implementation. For the project to be successful, an investment in AM training will be important. Possible sources include U.S. Department of Interior and other federally sponsored programs and the nongovernmental organization Foundation for Success, which has developed a software program called "Miradi" to help implement AM (Kapos et al. 2008). The Optimization Project will soon complete the first phase of its work - the collection of baseline data and initial stages of stakeholder involvement. A real commitment from the federal and state agencies involved, in particular Reclamation as operator of El Vado Dam, will be key to providing the necessary funding, authority, and administrative support.

\section{CONCLUSION}

Just as most rivers are not unequivocally either "runnable" or "unrunnable," the necessary capacity to engage in AM depends on a number of factors. In the case of the Rio Chama Optimization Project, both institutional and physical capacity issues will require careful maneuvering. We conclude that the Rio Chama is "runnable" from an AM perspective, but it will 
not be easy. Even if the project works within the physical limitations of the system, there are several Class III and IV issues that will provide challenges. This reinforces the point that, as is the case with whitewater, AM is not for the faint of heart. Even Class III rapids can flip a boat and toss the occupants into a turbulent situation. AM has an advantage in this respect: it anticipates this possibility and turns "failures" into opportunities for learning.

An important next step will be the development of numerical modeling tools that have the ability to incorporate a nuanced perspective on issues related to physical and institutional capacity. In systems like the Rio Chama, water operation models are used to prescribe and account for reservoir operations. These models provide a valuable tool for testing the feasibility and forecasting the expected results of AM scenarios. The current deterministic modeling approaches can be enhanced by incorporating probabilistic techniques that mirror the classification system proposed here. While current conceptual modeling in an AM context builds in issues related to ecological uncertainties, the classification framework has the potential to allow inclusion of legal and institutional uncertainties as well. The development of probabilistic techniques for both the physical and institutional elements has the potential to make the conceptual modeling processes that form scenario-based hypotheses more accurate while advancing the AM project more efficiently and effectively.

Using the classification system to identify capacity issues early in the development of the AM process will help the Optimization Project to stay afloat. As any experienced river runner knows, scouting difficult rapids helps. So does learning from others, in particular using guidebooks like the U.S. Department of Interior technical and applications guides (Williams et al. 2009; Williams and Brown 2012). Our classification scheme provides an approach for questioning whether AM will work in a given situation by providing a way of thinking though the various capacity issues involved.

Responses to this article can be read online at: http://www.ecologyandsociety.org/issues/responses. php/5707

\section{Acknowledgments:}

Thanks go to D. Llewellyn, M. Harvey, S. Harris, and the rest of the Rio Chama Optimization Team for their contributions, and to L.Morrison for editorial assistance. R. Morrison's work is supported by a fellowship from the Hydro Research Foundation.

\section{LITERATURE CITED}

Benson, M. H., and A. S. Garmestani. 2011. Embracing panarchy, building resilience and integrating adaptive management through a rebirth of the National Environmental Policy Act. Journal of Environmental Management 92:14201427.

Flanagan, K. J., and A. I. Hass. 2008. The impact of full beneficial use of San Juan-Chama Project water by the City of Albuquerque on New Mexico's Rio Grande Compact obligations. Natural Resources Journal 48:371-405.

Kapos, V., A. Balmford, R. Aveling, P. Bubb, P. Carey, A. Entwistle, J. Hopkins, T. Mulliken, R. Safford, A. Stattersfield, M. Walpole, and A. Manica. 2008. Calibrating conservation: new tools for measuring success. Conservation Letters 1:155-164. http://dx.doi.org/10.1111/j.1755-263X.2008.00025. $\underline{x}$

Nyberg, J. B., B. G. Marcot, and R. Sulyma. 2006. Using Bayesian belief networks in adaptive management. Canadian Journal of Forest Research 36:3104-3116. http://dx.doi. org $/ 10.1139 / \mathrm{x} 06-108$

Olsson, P., L. H. Gunderson, S. R. Carpenter, P. Ryan, L. Lebel, C. Folke, and C. S. Holling. 2006. Shooting the rapids: navigating transitions to adaptive governance of socialecological systems. Ecology and Society 11(1):18. [online] URL: http://www.ecologyandsociety.org/vol11/iss1/art18/

Peterson, G. D., G. S. Cumming, and S. R. Carpenter. 2003. Scenario planning: a tool for conservation in an uncertain world. Conservation Biology 17:358-366. http://dx.doi. org/10.1046/j.1523-1739.2003.01491.x

Porzecanski, I., L. V. Saunders, and M. T. Brown. 2012. Adaptive management fitness of watersheds. Ecology and Society 17(3):29. [online] URL: http://www.ecologyandsociety. org/vol17/iss3/art29/ http://dx.doi.org/10.5751/ES-05061-170329

Prato, T. 2003. Adaptive management of large rivers with special reference to the Missouri River. Journal of the American Water Resources Association 39:935-946. http://dx. doi.org/10.1111/j.1752-1688.2003.tb04417.x

Smith, C. B. 2011. Adaptive management on the central Platte River-science, engineering, and decision analysis to assist in the recovery of four species. Journal of Environmental Management 92:1414-1419. http://dx.doi.org/10.1016/j. jenvman.2010.10.013

Utton Transboundary Resource Center. 2012. Water matters: background on selected water issues. Albuquerque, New Mexico, USA.

Walters, C. J., and R. Hilborn. 1978. Ecological optimization and adaptive management. Annual Review of Ecology and Systematics 9:157-188. http://dx.doi.org/10.1146/annurev. es.09.110178.001105 
Williams, B. K., and E. D. Brown. 2012. Adaptive management: the U.S.Department of the Interior applications guide. Adaptive Management Working Group, U.S. Department of the Interior, Washington, D.C.

Williams, B.K.,R.C.Szaro, and C.D. Shapiro.2009.Adaptive management: the U.S. Department of the Interior technical guide. Adaptive Management Working Group, U.S. Department of the Interior, Washington, D.C. 